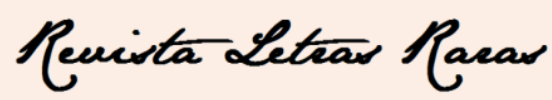

ISSN: 2317-2347 - Vol. 5, Ano 5, № 2 - 2016

\title{
Autorretrato de David Bailly: Quando as imagens extrapolam a vanitas
}

Prof. Dr. Jack Brandão ${ }^{1}$

Resumo: Um conceito muito abordado na arte seiscentista foi o de vanitas, gênero empregado por vários artistas no período, mas que se estendeu, inclusive, a nossos dias. Para demonstrar sua abrangência, servir-nos-emos de uma pintura do artista holandês David Bailly, que explorará várias de suas imagens em seu autorretrato, cotejando-as com as fontes bíblicas e com um gênero coetâneo, a emblemática.

Palavras-chave: Barroco, vanitas, emblemática, arte pictórica, Bíblia.

\section{Autorretrato de David Bailly: Quando as imagens extrapolam a vanitas}

\begin{abstract}
A concept much discussed in seventeenth-century art was the vanitas, gender employed by various artists in the period, but that extended even to our days. To demonstrate its reach, we will serve a painting of the Dutch artist David Bailly, who will explore several of his concepts in his self-portrait, comparing them with the biblical sources and with a coeval gender, the emblematic genre.
\end{abstract}

Keywords: Baroque, vanitas, emblematic genre, pictorial art, Bible.

Vanitas vanitatum dixit Ecclesiastes vanitas vanitatum omnia vanitas

$($ Ecl 1,2)

\section{Introdução}

Um dos temas mais empregados no século XVII foi, seguramente, o que diz respeito ao texto bíblico acima, retirado do livro do Eclesiastes. Não importa qual a língua falada - se latim, grego, castelhano, alemão, inglês, francês ou português -, a posição social - se nobre, se clérigo, se burguês, se povo -, o grau de instrução - se culto, doutor, medíocre ou mesmo analfabeto como a grande maioria -, ou a orientação religiosa - se católico ou protestante -, afinal todos se deixavam influenciar não só pela palavra vanitas, como também por tudo aquilo que se representava a partir desse conceito independente de qual fosse o meio escolhido, se pictórico, literário ou escultórico.

A vanitas deixa de ser uma mera palavra para se tornar um gênero, para o qual se confluíam as expressões artísticas do século XVII, em que se manifestava a relação

\footnotetext{
${ }^{1}$ Mestre e Doutor em Literatura pela Universidade de São Paulo (USP), Professor Titular do Mestrado Interdisciplinar em Ciências Humanas da Universidade de Santo Amaro (UNISA/SP) e coordenador do Grupo de Pesquisa CONDESIM-FOTÓS/DGP-CAPES.
} 


\section{Revista Leteras Raear}

ISSN: 2317-2347 - Vol. 5, Ano 5, № 2 - 2016

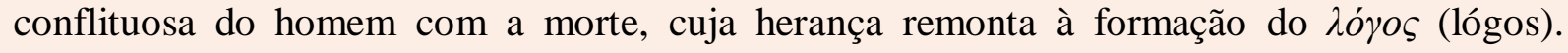
(BRANDÃO, 2009)

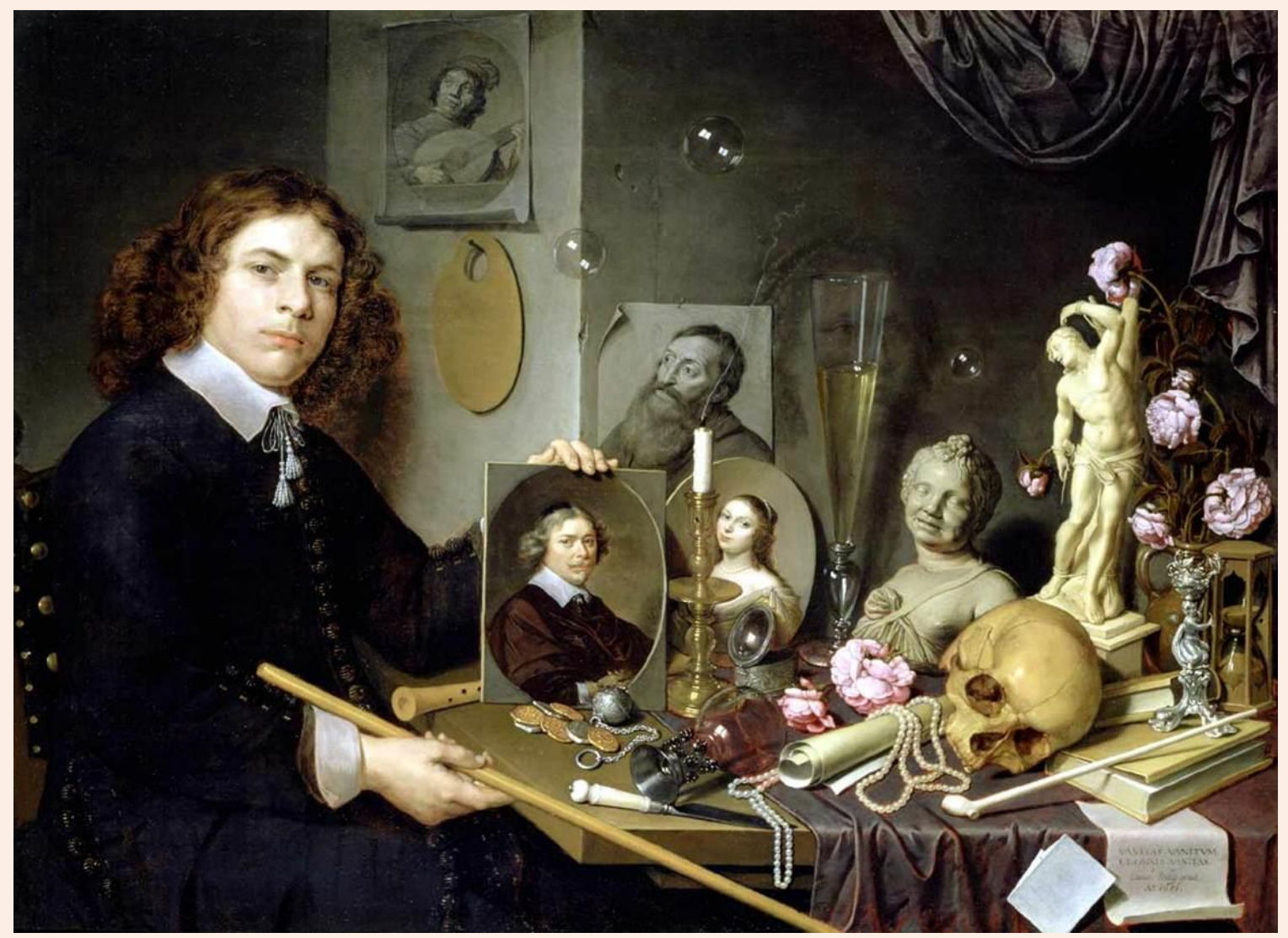

Figura 1: Autorretrato com símbolos da vanitas, de David Bailly, 1651

$\mathrm{Na}$ arte pictórica, lembra-nos o emprego de naturezas-mortas, no entanto, às frutas e aos animais são acrescidas - quando não substituídas - outras imagens que eram plenamente decodificadas pelo homem seiscentista, mas que para nós podem passar despercebidas, como a fumaça que sai de uma vela recém-apagada, um canto esmoucado de uma parede, moedas largadas em uma mesa, ou mesmo taças de vinho emborcadas.

A obra "Autorretrato com símbolos da vanitas" do artista plástico holandês David Bailly (1584-1657) fornecerá elementos para esta análise; mas, para isso, faz-se necessário não apenas conhecer, como também empregar elementos da Weltanschauung do século XVII, como os da emblemática e os da tradição bíblica - afinal o termo foi tomado de empréstimo do livro do Eclesiastes da Bíblia -, para que se abra o leque da compreensão dos elementos imagéticos empregados no quadro.

Iniciaremos nossa primeira leitura da pintura, empregando o modelo de Erwin Panofsky (2001), para quem é possível identificar três níveis no significado de uma obra de 


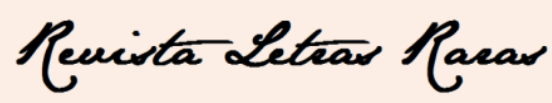

ISSN: 2317-2347 - Vol. 5, Ano 5, № 2 - 2016

arte, com os quais poderemos compreender o que o autor alemão entende por iconografia e iconologia:

a) tema primário ou natural (descrição pré-iconográfica): identificação das formas básicas de uma expressão artística, tendo por base nossa experiência prática em relação às cores, às linhas e aos volumes e aos materiais identificados com as formas animadas ou inanimadas (homens, animais, plantas, objetos etc.) como bronze, madeira, pedra, além da percepção de alguns modos de expressão como alegria, tristeza, raiva;

b) tema secundário ou convencional (descrição iconográfica): ligação de motivos artísticos e suas combinações com assuntos ou conceitos que podem ser reconhecidos como portadores de significados, como as alegorias - o que pressupõe, portanto, familiaridade com temas ou conceitos específicos (imagens católicas retratadas com uma palma nas mãos representam martírio, por exemplo) - demandando, dessa forma, uma busca por conhecimentos prévios para sua interpretação;

c) significado intrínseco ou conteúdo (descrição iconológica): apreensão de princípios subjacentes que "revelam a atitude básica de uma nação, de um período, classe social, crença religiosa ou filosófica" (PANOFSKY, 2001, p. 52), dessa forma requer mais do que familiaridade com determinados conceitos, ou, como diz Panofsky, temos de ter "uma faculdade mental comparável à de um clínico nos seus diagnósticos”. (ibidem, p. 62) Deve-se, portanto, buscar as respostas para possíveis questionamentos na obra, não apenas e exclusivamente em uma única, mas no

grupo de obras, a que devota sua atenção, com base no que pensa ser o significado intrínseco de tantos outros documentos da civilização historicamente relacionados a esta obra ou grupo de obras quantos conseguir: de documentos que testemunhem as tendências políticas, poéticas, religiosas, filosóficas e sociais da personalidade, período ou país sob investigação. (ibidem, p. 63)

Assim, ao fazermos nossa leitura pré-iconográfica do quadro de Bailly seria possível enxergar: a) um jovem com roupas escuras, sentado numa cadeira com botões, segurando um bastão na mão direita e mostrando-nos um retrato de uma pessoa idosa; b) o jovem sentado demonstra altivez mesclada com orgulho; c) a mesa está coberta com uma toalha de tonalidade escura, porém há uma parte levantada onde se veem um cálice de vinho deitado, moedas, um relógio de pulso, uma flauta e uma faca - provavelmente para abrir envelopes - e sobre a toalha temos um colar de pérolas, um crânio, um castiçal cuja vela fora apagada há 


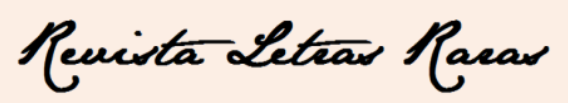

ISSN: 2317-2347 - Vol. 5, Ano 5, № 2 - 2016

instantes, duas flores murchas, uma vasilha de água (parecida com uma taça de espumante, mas que, provavelmente, é um receptáculo para água que será misturado à tinta), um quadro de mulher, um busto de um menino, dois livros, uma ampulheta, uma pequena imagem que nos lembra São Sebastião, um vaso com flores murchas, uma piteira longa, uma caixinha (parece ser de prata), sob um livro e caindo fora da mesa algo que parece ser um bilhete dobrado e um papel aberto com os dizeres Vanitas Vanitatum et Omnia Vanitas; d) no canto direito há uma cortina de cor escura drapeada; e) acima do quadro de mulher, vê-se uma gravura de homem e, na mesma parede, um vulto de mulher; f) veem-se, no ambiente, bolhas de sabão flutuando no ar; g) há, na parede onde a palheta está pendurada, um quadro onde se vê um trovador; h) no canto direito há uma cortina de cor escura drapeada; e i) é possível ver, na quina da parede, uma parte em que há uma lasca.

Ao passarmos a nossa análise iconográfica, percebemos que, enquanto em grande parte da Europa havia muitos quadros com motivos religiosos (temas bíblicos ou hagiográficos), o quadro de Bailly não remete, pelo menos aparentemente, a nenhum deles. É possível explicar isso devido à prosperidade econômica da sociedade holandesa que não restringia ao clero nem à nobreza o acesso à arte, mas a uma forte classe média urbana. O país praticamente desconheceu o mecenato eclesiástico e cortesão, resultando dessa forma representações da vida cotidiana, aquilo que, comumente, era chamado de paisagem vista da janela.

São facilmente perceptíveis, na pintura, imagens que demonstram a fugacidade do tempo, como a vela apagada, o crânio, a ampulheta, as flores murchas: imagens/conceitos mais conhecidos da vanitas - que não passavam de lugares-comuns utilizados por grande parte dos pintores do período -, conforme o título da pintura sugere. As flores, por exemplo, remontam à tradição bíblica tanto no Antigo:

Todo ser humano é erva e toda sua beleza é como a flor do campo: a erva seca, a flor murcha, quando sobre elas sopra o vento de Javé; a erva seca, a flor murcha, mas a palavra do nosso Deus se realiza sempre. (Is 40,6-8)

Quanto no Novo Testamento:

Olhem como crescem os lírios do campo: eles não trabalham nem fiam. Porém eu lhes digo: nem o rei Salomão, em toda a sua glória, jamais se vestiu como um deles. Ora, se Deus assim veste a erva do campo, que hoje existe e amanhã é queimada no forno (...). (Mt 6, 28-30) 


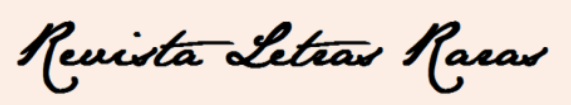

ISSN: 2317-2347 - Vol. 5, Ano 5, № 2 - 2016

A ampulheta e o relógio de bolso, devido à natureza de seu emprego, corroboram a passagem do tempo e nossa escravidão em relação a ele. $\mathrm{O}$ mesmo pode ser dito a respeito do crânio que é, de per si, o resultado da morte, sua forma mais visível. Ou seria o resultado futuro das duas personagens retratadas no quadro? Não se pode esquecer de que o pintor se retrata jovem exibindo-se quando idoso. Normalmente, a relação deveria inversa, ou seja, o homem maduro é que, a priori, teria de apresentar o jovem, já que a maturidade seria seu tempo presente. Vê-se, portanto, a passagem do tempo e da juventude, realizado como um jogo de prestidigitação do artista. Temos, assim, o resultado do presente (velho), passado (jovem) e futuro (caveira). Em seu autorretrato, Bailly jovem é representado com convencimento e orgulho próprios da juventude, repleta dos hormônios e da gana de autossuficiência que o pintor soube muito bem representar. Em contraste, há um Bailly velho, demonstrando serenidade e aceitação, características próprias da idade madura. Dessa forma, a vanitas é posta em destaque a partir do próprio eu criador, quando nos mostra o resultado da fugacidade da vida em si mesmo: fui assim; agora, sou assim; amanhã serei...

Não obstante o fato de não haver uma temática religiosa no quadro, há o versículo do Eclesiastes no canto direito da obra - VANITAS VANITATUM ET OMNIA VANITAS - que nos deve remeter a uma leitura sob um prisma religioso realçando o conceito de vanitas. Dessa maneira, pode-se supor que a obra realmente tenha como temática o texto bíblico. Este questiona logo em seu início: "Que proveito tira o homem de todo o trabalho com que se fadiga debaixo do sol?" (Ecl 1,3)

Mais que uma pergunta ontológica, o que vemos a seguir é uma série de fenômenos naturais que sempre se repetem sem a interferência humana, num continuum cíclico natural:

Geração vai, geração vem, e a terra permanece sempre a mesma. O sol se levanta, o sol se põe (...). O vento sopra para o sul, depois para o norte (...). Todos os rios correm para o mar, e o mar nunca transborda (...). O que aconteceu, de novo acontecerá; e o que se fez, de novo será feito: debaixo do sol não há novidade. (...) Ninguém se lembra dos antigos, e aqueles que existem não serão lembrados pelos que virão depois deles. (Ecl 1, 4-11).

Há, nesse capítulo inicial do Eclesiastes, uma verdadeira síntese daquilo que será abordado pelo livro, apontando, consequentemente, a inutilidade de todo o esforço humano. Isso só foi percebido, segundo o eu bíblico, após o mesmo ter investigado e pesquisado a partir da luz da sabedoria (Ecl 1,13-15). A conclusão a que se chegou foi: "tudo é fugaz, uma 


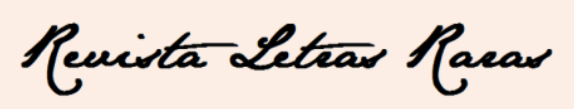

ISSN: 2317-2347 - Vol. 5, Ano 5, № 2 - 2016

corrida atrás do vento." (Ecl 1, 14). Apesar de conscientizar-se de que tenha adquirido "ciência e sabedoria", decide ir além e propõe-se também a conhecer a "tolice e a loucura", mas também conclui que "isso é correr atrás do vento, porque onde há muita sabedoria, há muita tristeza, e onde há mais conhecimento, há também mais sofrimento”. (Ecl 1, 16-18).

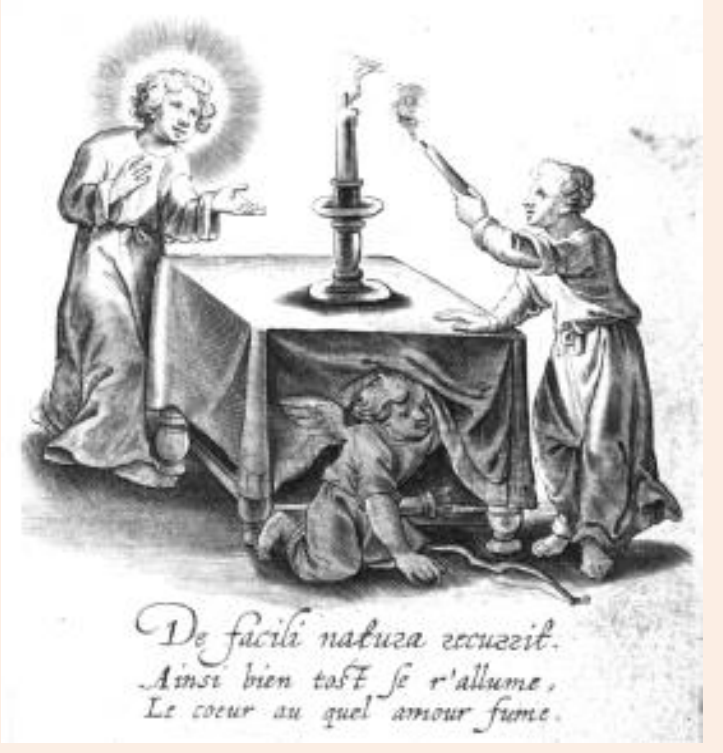

Figura 2: Emblema 33, Renovatio Amoris, de Ludovicus van Leuven, 1629

Diante disso, parte em busca de experimentar a alegria, de conhecer o prazer. No entanto, também descobre neles a fugacidade. Não satisfeito, procura realizar grandes obras:

Construí palácios (...), plantei vinhas, fiz jardins e pomares (...) construí reservatórios de água (...). Comprei escravos (...), tive muitos criados (...). Possuí muitos rebanhos (...). Acumulei prata e ouro (...). Arranjei cantores e cantoras e-delícias dos homens - princesas em grande número.

Não recusei nada do que meus olhos pediam, e nunca privei o meu coração de nenhum prazer. Sabia desfrutar de todo o meu trabalho (...).

Então examinei todas as obras que havia feito e o trabalho que elas tinham custado para mim. E concluí que tudo é fugaz e uma corrida atrás do vento, e que não há nada de permanente debaixo do sol. (Ecl 2, 3-12)

O eu bíblico perde, portanto, não só sua esperança como também alimenta o ódio pela vida, afinal tudo sob o sol o desagradou e nada permanece, a não ser o desalento de ter se fatigado duramente para ter de deixar aos outros, que nada fizeram, o resultado de seu suor:

Detesto todo o trabalho com que me afadigo debaixo do sol, porque devo deixar tudo para o homem que virá depois de mim. (...) ele será dono de tudo o que eu fiz debaixo do sol com a minha fadiga e sabedoria. Também isso é fugaz. Então fiquei com o coração desesperado por causa de todo o

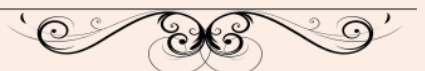




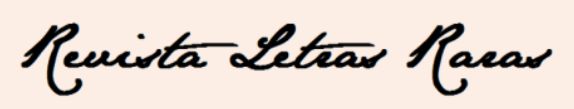

ISSN: 2317-2347 - Vol. 5, Ano 5, № 2 - 2016

trabalho com que me afadiguei debaixo do sol. (...) E depois tem que deixar seus bens para outro que nada se afadigou.

Então, que proveito resta para o homem de todo o trabalho e esforço mental com que se afadigou debaixo do sol?(...) seus dias todos são dolorosos, a sua tarefa é penosa, e até a noite ele não pode repousar. (Ecl 2, 18-23)

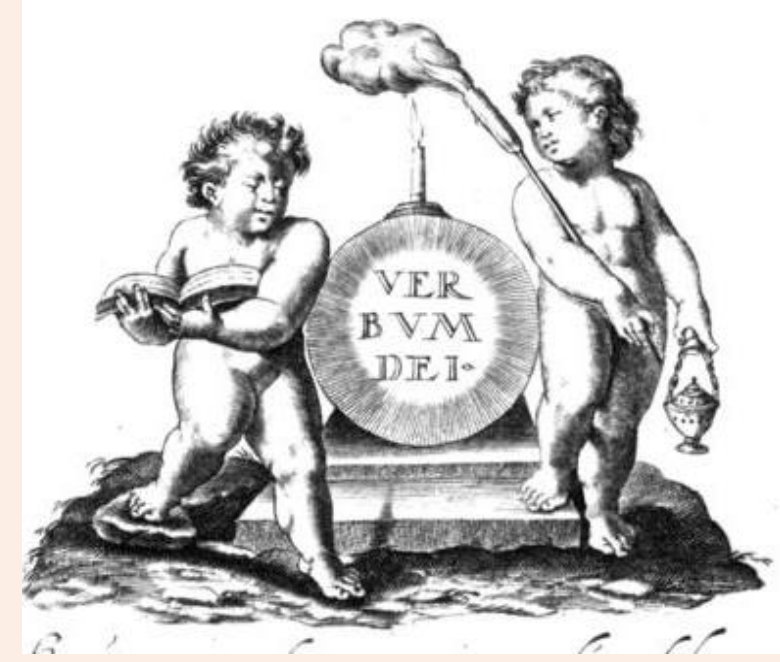

Figura 3: Emblema 49, Exiccatur foenum, et cadit flos, anônimo, 1628.

O Eclesiastes pertence aos chamados livros sapienciais e, por mais pessimista que pareça, o eu bíblico mostra-se crítico, lúcido e realista, mesmo que de forma inconformista, quanto ao ritmo da vida e da impotência do homem face à realidade inexorável da morte. Ao buscar a mesma dinamicidade da vida, o eu bíblico faz emprego de antinomias, paradoxos, enigmas, repetições, a fim de nos demonstrar sua máxima: "tudo é fugaz!"

Ao vermos a obra de Bailly e a confrontarmos com o texto bíblico, fica difícil estabelecermos, de forma direta, uma correspondência, por isso é mister irmos além e procurarmos as respostas na análise de alguns elementos iconológicos da pintura para que nos forneçam as respostas para uma análise mais abrangente. Dessa forma, retiraremos do quadro alguns elementos para analisá-los individualmente, a fim de podermos cotejá-los com outra expressão artística do momento: a emblemática ${ }^{2}$.

\footnotetext{
${ }^{2}$ Os emblemas possuíam uma estrutura tripartite constituída por uma imagem - seu corpo - que deveria ser fixada na memória dos leitores, pois ela passava preceitos morais que o autor desejava transmitir; um mote, normalmente uma sentença aguda escrita em latim, a partir do qual o leitor era direcionado a determinada leitura da imagem; e um epigrama, ou texto explicativo, que buscava relacionar o corpo com o mote do emblema, clarificando a relação existente; era, portanto, sua alma. (BRANDÃO, 2008, p. 315)
} 


\section{Revista Leteas Raear}

ISSN: 2317-2347 - Vol. 5, Ano 5, № 2 - 2016

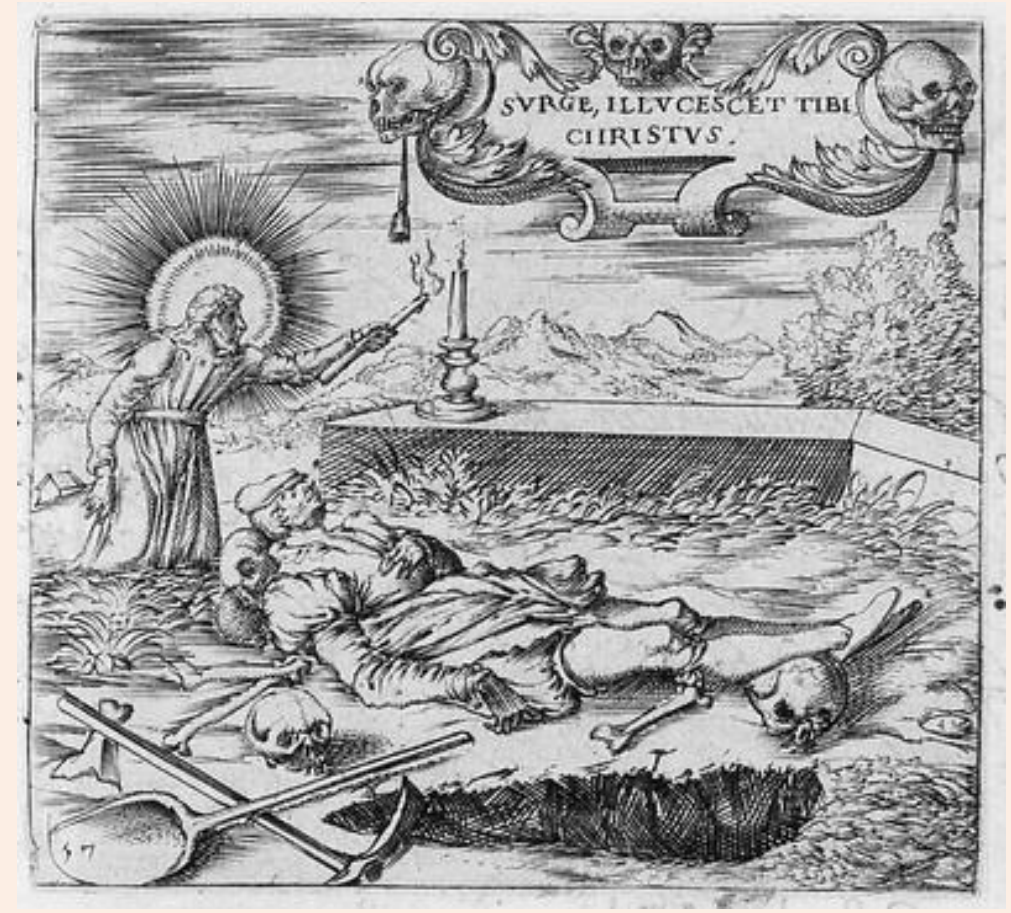

Figura 4: Emblema 57, Surge, illucescet tibi Christus, Gerogete de Montenay, 1615.

\section{Vela apagada há poucos instantes}

No Sábado de Aleluia, todas as luzes das igrejas católicas são apagadas, as pessoas saem e, após uma cerimônia fora do templo, quando o sacerdote abençoa o fogo, um grande círio é aceso nele. A seguir, o padre com o círio em suas mãos, entra na igreja escura iluminando o ambiente, quando várias outras velas são acesas nele. A vela, na tradição cristã, representa Cristo ressuscitado, no caso simbolizado pelo círio; as outras velas simbolizam as pessoas que têm de passar essa boa nova para as outras (fig. 2), não só renovando a esperança na Boa Nova do Ressuscitado, como também demonstrando ser ele mesmo luz do mundo: "Vocês são a luz do mundo. (...) que a luz de vocês brilhe diante dos homens, para que eles vejam as boas obras que vocês fazem (...)”. (Mt 5, 14-16) 


\section{Reuista Letear Pacar}

ISSN: 2317-2347 - Vol. 5, Ano 5, № 2 - 2016

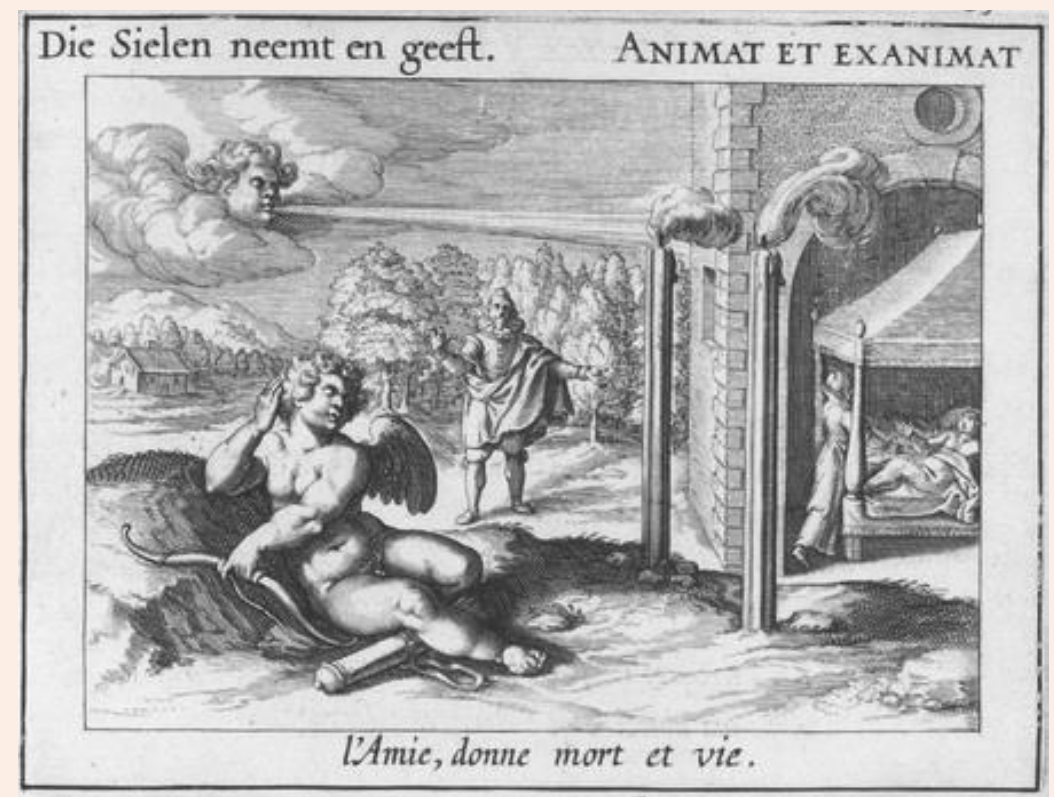

Figura 5: Emblema 26, Die sielen neemt en gheeft, de Pieter Cornelisz, 1611.

O tema será tratado em várias coleções de emblemas como na obra Amoris divini et humani antipathiae, de 1628. Em seu emblema 46 (fig. 3), vemos duas crianças: uma com um livro - provavelmente a Bíblia que, por meio da interpretação figural (AUERBACH, 2004, p. 62-65), predizia a vinda do Messias - a outra segura uma tocha e um turíbulo. Ambas dirigem o olhar para um círculo luminoso, sobre o qual vemos uma vela acesa, em que está escrito: Verbum Dei. Por isso uma criança tem o turíbulo em sua mão: o incenso é para ser oferecido à Divindade de Cristo. Além de Verbo de Deus, São João chama Jesus de Luz: "Nela [a Palavra, o Verbo] estava a vida, e a vida era a luz dos homens. Essa luz brilha nas trevas, e as trevas não conseguiram apagá-la”. (Jo 1, 4-5) Tal tema será retomado por São Paulo que, ao se referir a Jesus ressuscitado, diz que Ele ilumina mesmo os que já se foram:

Outrora vocês eram trevas, mas agora são luz no Senhor. Por isso comportem-se como filhos da luz. (...). É por isso que se diz: "Desperte, você que está dormindo. Levante-se dentre os mortos, e Cristo o iluminará." (Ef 5, 8,14)

A vela acesa é a Luz Divina que ilumina e dá a vida. No entanto, quando está apagada é sinal de morte, de fim, como vemos na fig. 4. Ali a chama da esperança/vida está apagada, os mortos esperam-nos: vemos a cova, os crânios, a pá e a picareta. Quem pode reverter isso é Cristo, ao (re)acender a vela, quebrando, momentaneamente, o domínio da morte, trazendonos, de novo, ao reino fatídico da vanitas. Assim como Deus dá a vida, ele pode tirá-la com 


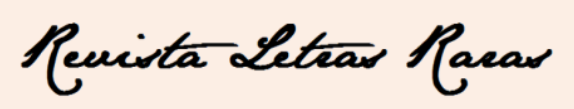

ISSN: 2317-2347 - Vol. 5, Ano 5, № 2 - 2016

seu sopro divino: deste modo, o mesmo sopro que nos faz respirar é aquele que nos faz inertes (fig. 5).

Eis a ideia expressa na obra de Bailly (e eis como os leitores dos Seiscentos liam a vela apagada): basta o vento para apagá-la, mesmo que ela tenha sido luz, mesmo que sejamos filhos da luz, esta tem de regressar de onde veio que é a escuridão da morte. Para aqueles que creem essa não é o fim, mas o renascimento, pois:

fomos sepultados com Ele na morte, para que, assim como Cristo foi ressuscitado dos mortos por meio da glória do Pai, assim também nós possamos caminhar numa vida nova. $(\mathrm{Rm} 6,4)$

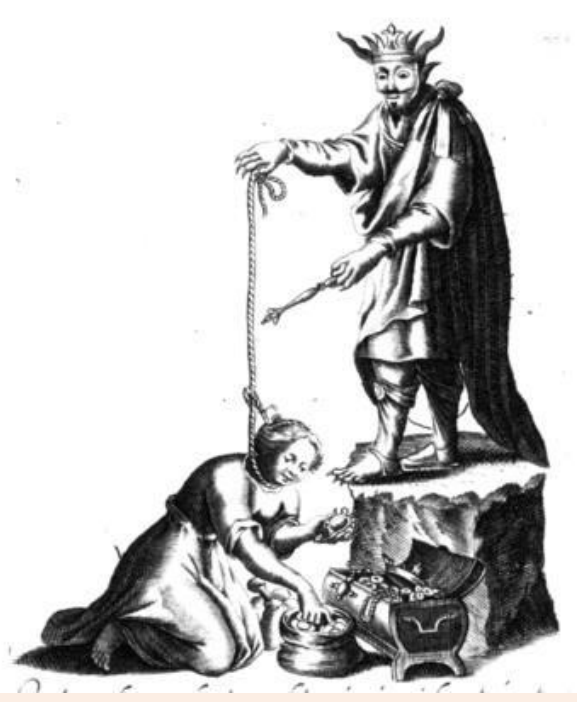

Figura 6: Emblema 5, Laqueus amoris mundani, 1628.

\section{Moedas}

As moedas, evidentemente, simbolizam a fortuna, a ostentação, a riqueza, o dinheiro. Este pode vir do esforço do trabalho - portanto, abençoado por Deus - e da manutenção/perpetuação da opressão dos maiores sobre os menores, ou seja, do pecado, enquanto desvio das normas morais estabelecidas por determinada sociedade e ratificadas por sua divindade. A cobiça, a luxúria e a tirania são, portanto, formas que desagradariam a Deus, mas não ao Satanás. Essa ideia será recorrente no Seiscentismo, visto que o domínio do dinheiro - devido ao poder que a própria burguesia estava assumindo - era cada vez maior, instaurando o domínio do capitalismo como regulador social.

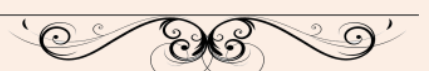




\section{Reuista Letear Pacar}

ISSN: 2317-2347 - Vol. 5, Ano 5, № 2 - 2016

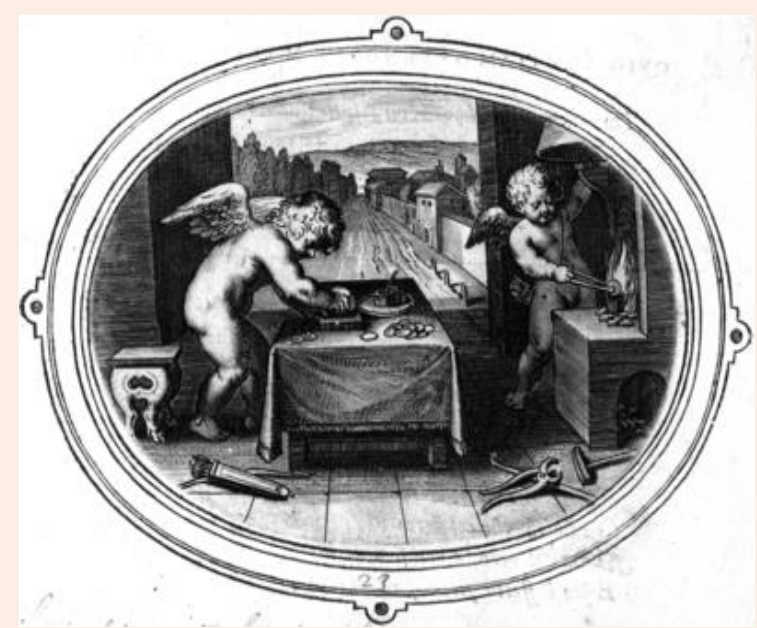

Figura 7: Emblema 41, Nil aurei? nil te coronati juuant, 1617.

A emblemática empregará a imagem/conceito da moeda sob diversos parâmetros: como forma de o homem se escravizar por:

desejos insensatos e perniciosos, que fazem os homens afundarem na ruína e perdição. Porque a raiz de todos os males é o amor ao dinheiro. Por causa dessa ânsia de dinheiro, alguns se afastam da fé e afligem a si mesmos com muitos tormentos. (1Tim 6, 9-10)

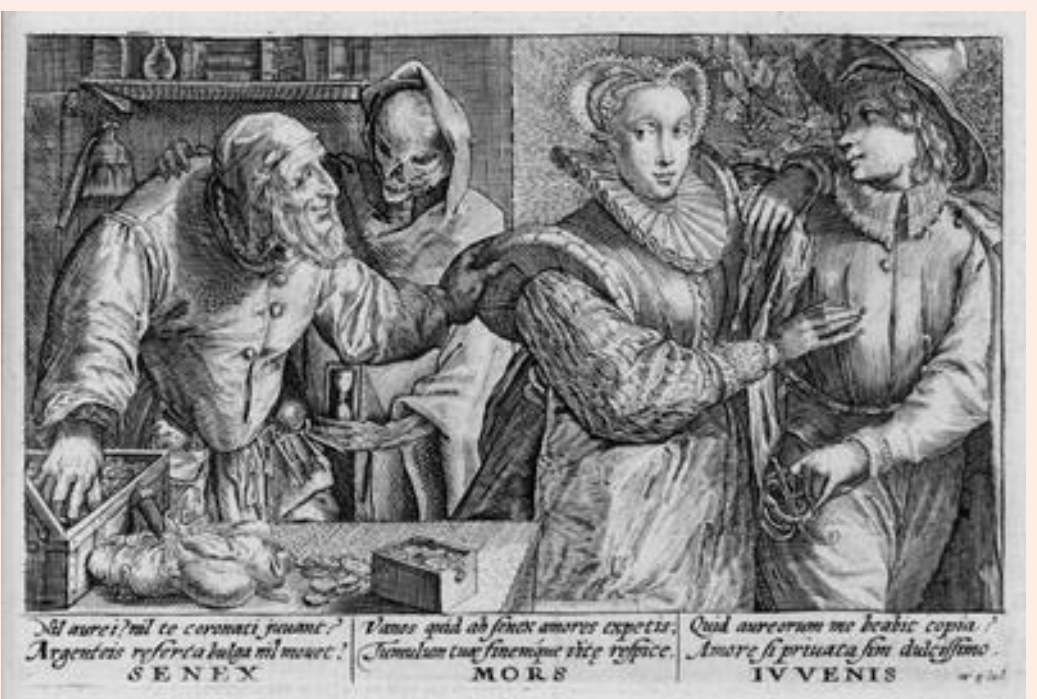

Figura 8: Emblema 23, Amor certus in re incerta cernitur, de Otto Vaenius, 1608

Observamos isso na figura 6 , quando vemos uma pessoa ajoelhada - em sinal de adoração - diante do dinheiro, mas na realidade ajoelha-se diante do Demônio. Escravizado, o homem se sujeita a tudo. Atado - simbolizado pela corda enlaçada ao pescoço do subjugado - 


\section{Revista Leteas Raear}

ISSN: 2317-2347 - Vol. 5, Ano 5, № 2 - 2016

está aos bens terrenos e sob o domínio do Príncipe do mundo, o Satanás - por isso, a coroa, o cetro e o manto -, que o leva aonde quer, privando-o da graça de Deus, a quem abandonou.

O dinheiro quer poder comprar tudo, inclusive a felicidade e o amor, de modo que aqueles que o têm, acreditam poder comprar a afeição dos outros (fig. 7). A emblemática nos mostra isso quando vemos um velho tentando comprar o amor de uma jovem ao exibir-lhe sua riqueza, simbolizada pela urna de moedas que tem diante de si, mas que recebe o desprezo dela, que prefere um rapaz de sua própria idade. Ao lado do ancião vemos a caveira simbolizando a morte e trazendo a ampulheta, mostrando-nos que seu tempo chegará em breve.

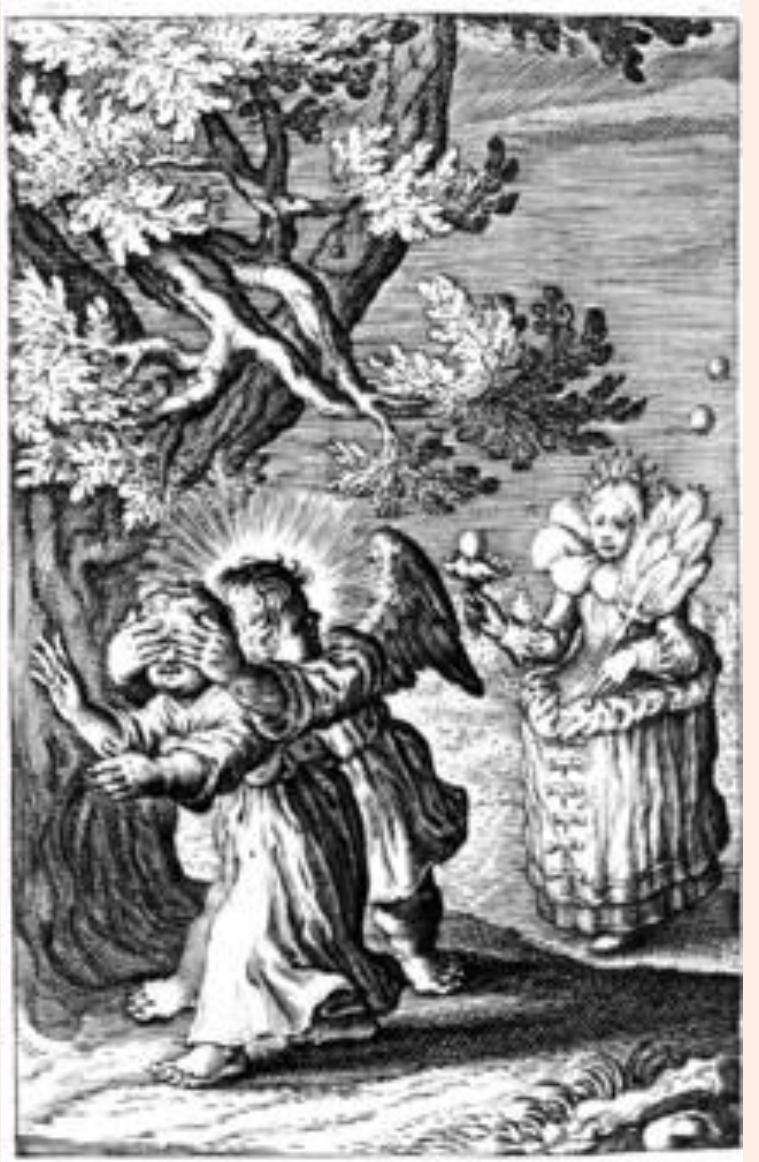

Figura 9: Emblema 20, Auerte oculos meos ne vide, de Justus de Harduwijn, 1629

A morte, à espreita, diz que o tempo é curto. Mas tempo de quem? De quem compra, de quem é comprado, ou da riqueza que com a mesma facilidade com que vem, vai embora? Dessa forma, a citação direta de fortuna - moedas de ouro e prata, bem como objetos preciosos - representa a vanitas, pois são bens efêmeros que, por mais que os possuamos, não poderemos levar para o outro mundo. 


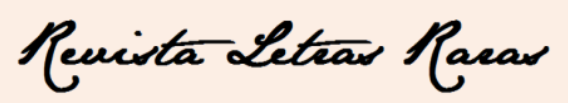

ISSN: 2317-2347 - Vol. 5, Ano 5, № 2 - 2016

Apesar dessa conotação negativa, as moedas também podem simbolizar a pureza e isso só é possível no fogo (fig. 8), pois é ali que se comprova sua qualidade. De maneira semelhante, a fé e a constância - a Deus, ao amor, a um ideal -, também segundo preceitos bíblicos, são provadas na adversidade:

Meu filho, se você se apresenta para servir ao Senhor, prepare-se para a provação. (...) aceite tudo o que lhe acontecer, e seja paciente nas situações dolorosas, porque o ouro é provado no fogo e as pessoas escolhidas, no forno da humilhação. (Ecl. 2, $1,4-5)$

\section{Bolhas de sabão}

Bolhas de sabão são por sua própria natureza frágeis e fugazes, por isso também representam a vanitas. Foram, portanto, não só exploradas pela emblemática (fig. 9 e 10), como também pela poética do período. Justus de Harduwijn explora o conceito/imagem em seu emblema 20, quando vemos o Amor Sagrado cobrindo os olhos da Alma humana para que esta não visse a personificação da vanitas (futilidade, inutilidade). O título desse emblema provém do livro dos Salmos: "Evita que meus olhos vejam o que é inútil, dá-me vida, pela tua palavra”. (S1 119, 37) 


\section{Reuista Letear Pacar}

ISSN: 2317-2347 - Vol. 5, Ano 5, № 2 - 2016

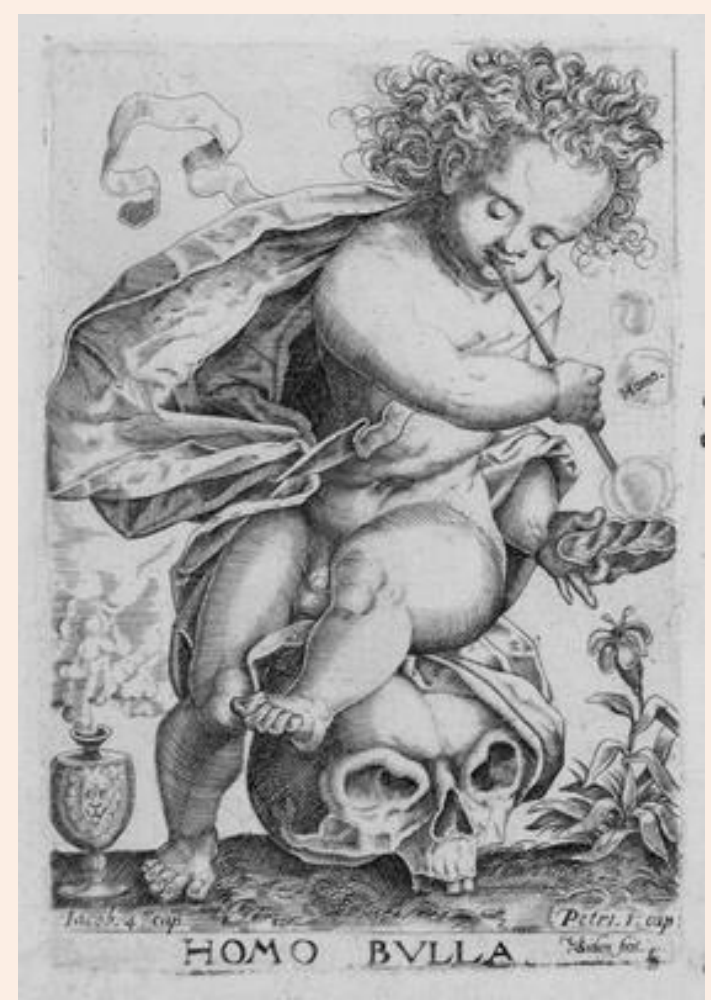

Figura 10: Emblema 49, Homo bulla, anônimo, 1617.

Mais expressivo, no entanto, é o emblema Homo bulla [homem bolha] que retrata exatamente a efemeridade do homem quando este é, metaforicamente, uma bolha cujo resultado é o crânio sob a criança que brinca de fazer bolhas de sabão. Além destas há também outras evidências da vanitas, como a fumaça que se lança no ar e a flor.

\section{Crânio, esqueleto, ossos}

O crânio, os ossos ou todo o esqueleto são, sem dúvida, os elementos de maior impacto referentes à temática da vanitas: é o resultado visível da ação da efemeridade da vida e de seu triunfo.

Várias foram as representações da morte na emblemática, como aquela em que vemos um esqueleto, em atitude imperiosa, montado sobre um crocodilo (fig. 11). É interessante a dupla significação desse emblema, pois se a morte pode ser considerada negativa, visto que arranca, destrói e nos reduz a cinzas, o crocodilo, devido à sua ferocidade, corrobora a própria imagem da morte. Horapolo afirma que, para os egípcios, o animal representava fúria e proliferação: "Por su extrema rapacidad (...) fue jeroglífico de la ruina y destrucción, pues es muy peligroso y su mordisco incurable". (HORAPOLO, 1991, p.160). Os antigos viam-no 


\section{Reuista Letear Racar}

ISSN: 2317-2347 - Vol. 5, Ano 5, № 2 - 2016

como o símbolo da própria maldade, sendo venerado inclusive pelos egípcios como um deus, pelo medo que inspirava. (ibidem, p. 160) O emprego das duas imagens, talvez, remeta não só ao fato da ferocidade de ambos (da morte e do crocodilo), mas também, como foi dito, por se proliferarem em abundância, chegando a por mais de sessenta ovos de uma só vez.

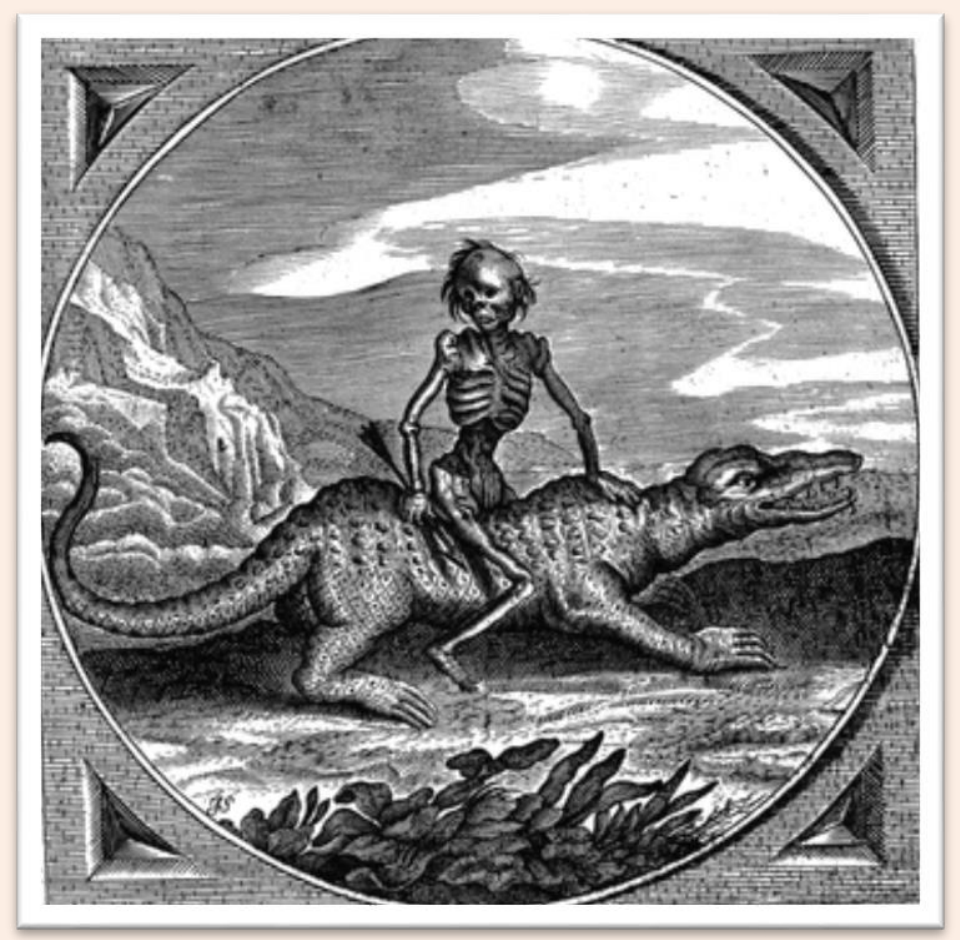

Figura 11: Emblema 46, Nescit habere modum, de Jacob Cats, 1627.

Deste modo, o nosso emblema chega a ser mais um jogo barroco, um paradoxo imagético conceitual. Afinal, que é a morte senão o renascer das cinzas em seu perpétuo continuum, quando a matéria morta se incorpora na matéria viva? Que melhor representação para a morte que a de reproduzir-se indefinidamente ${ }^{3}$, numa época marcada por contínuas guerras como a dos Trinta Anos, que não parava de ceifar vidas numa proliferação de destruição quase sem fim?

\footnotetext{
${ }^{3}$ Por isso Ripa também nos mostra o crocodilo em sua representação da luxúria, quando se vê uma mulher desnuda sentada sobre um crocodilo, "porque ya decían los Egipcios que dicho animal era símbolo de Lujuria, en atención a su caracter fecundísimo, pues en efecto engendra muchos hijos; y (...) es de tan contagiosa libinosidad que, según se cree comúnmente, atando al brazo diestro los dientes de su mandíbula superior, pueden excitar y provocar nuestra lujuria". (RIPA, 2007, p. 34)
}

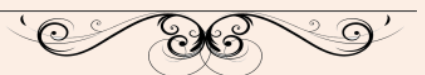




\section{Penista Leteas Pacar}

ISSN: 2317-2347 - Vol. 5, Ano 5, № 2 - 2016

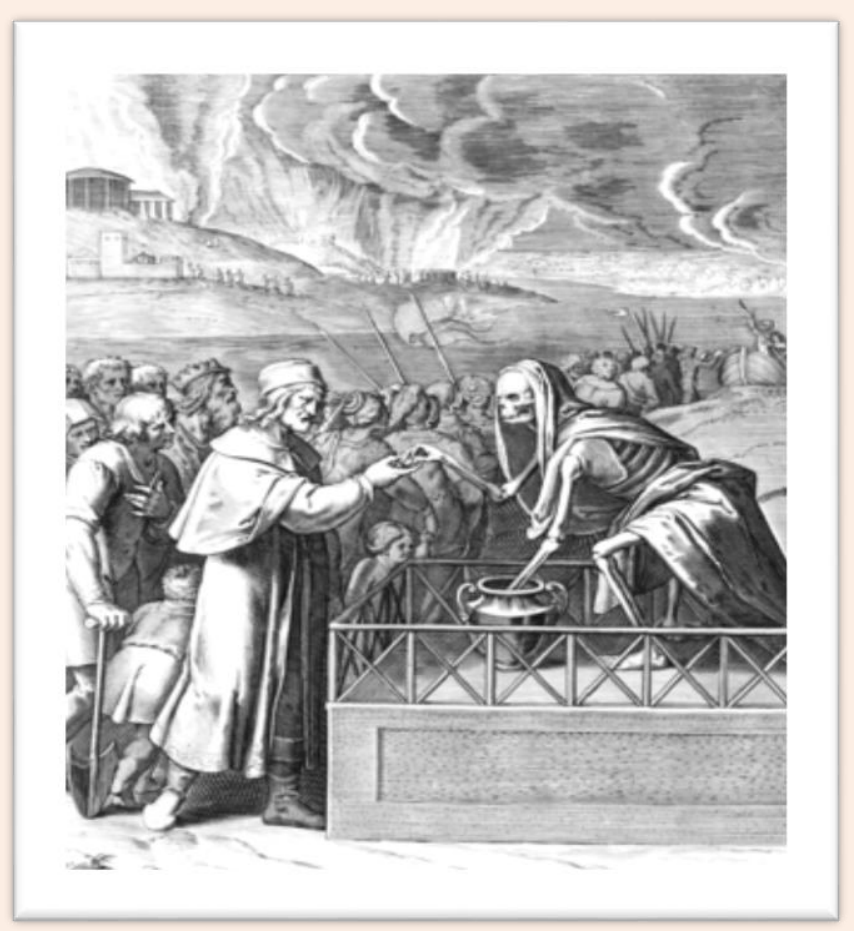

Figura 12: Emblema 98, Mortis certitudo, de Otto Vaenius, 1612

Conforme demonstra Maravall, a familiarização com a violência decorrente do “espetáculo cotidiano da repressão e da guerra" (MARAVALL, 1997, p. 268) contribuiu não só para a inclinação pela crueldade ${ }^{4}$, como também “orientava todo o delineamento patético e pessimista do Barroco, a fim de pôr às claras a condição humana para dominá-la, contê-la e dirigi-la." (ibidem, p. 268) Isso seria perfeitamente possível, visto ser essa a realidade presenciada por todos diante do fétido odor de morte que se espalhou pela Europa durante a Guerra dos Trinta Anos. Além disso, ninguém está protegido da morte: esta não escolhe suas vítimas pela posição social, por sua inteligência ou por suas posses. Todos são convocados ao seu chamado e convidados a entrar no barco que os levará para o outro lado do rio (fig. 12). Há, no emblema 98 de maneira bem clara, o fato de todos, sem exceção, se verem diante da morte, principalmente em tempo de guerra (representada pelas labaredas e pela fumaça) seja o rei (representado com a coroa), seja o camponês (que traz a pá como instrumento de trabalho). Convém lembrarmos que a guerra, por exemplo, naquele período era encargo da nobreza:

\footnotetext{
${ }^{4}$ Refletida, muitas vezes, nas Trauerspiele alemãs como a Sophie de Hallmann, quando se mostra que, após o martírio imposto a uma cristã e a suas filhas, suas cabeças, decapitadas, são exibidas no palco como em um banquete dos mortos (BENJAMIN, 2013). O poeta alemão Andreas Gryphius também utilizava cadáveres e mortes no palco; o mesmo expediente também era encontrado nos palcos espanhóis. (MARAVALL, 1997)
} 


\section{Pevista Leteas Pacar}

ISSN: 2317-2347 - Vol. 5, Ano 5, № 2 - 2016

eram os reis, os príncipes e os nobres que se dirigiam para o front ${ }^{5}$, fato que começa a mudar com o desenvolvimento do capitalismo, quando nobres enviam prepostos em seu lugar em troca de pagamento.

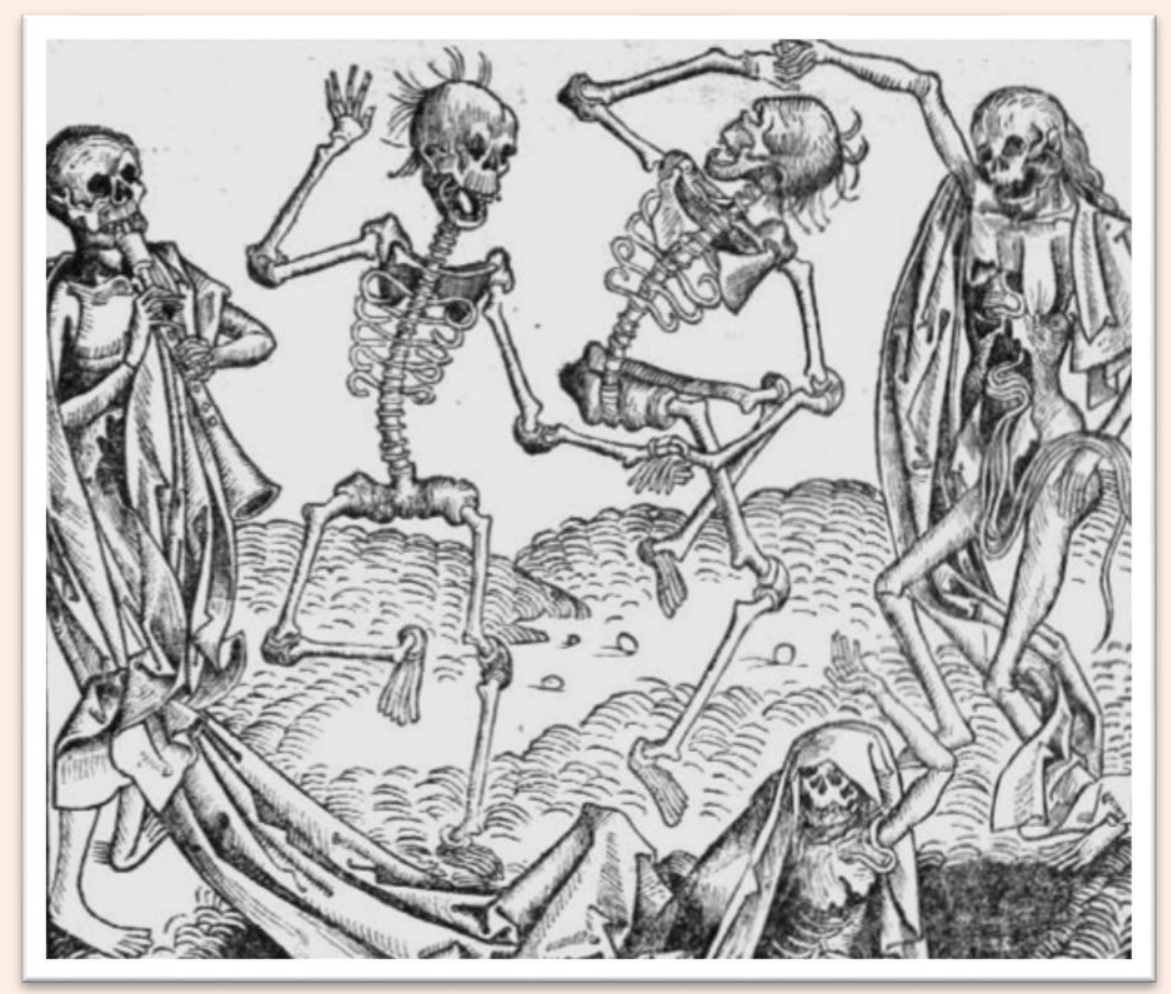

Figura 13: "Dança macabra", gravura do livro Liber Chronicum, de Hartmann Schedel, 1493.

Essa obsessão mórbida, contudo, não é exclusividade do século XVII, nem mesmo da centúria anterior, vemo-la também na Idade Média nas gravuras representando a dança macabra e a dança de $\operatorname{esqueletos}^{6}$ (fig. 13), cujo caráter era didático e impessoal (MARAVALL, 1997, p. 268), logo não correspondiam à ideia escatológica cristã do Juízo Final:

Não fiquem admirados com isso, porque vai chegar a hora em que todos os mortos que estão nos túmulos ouvirão a voz do Filho, e sairão dos túmulos: aqueles que fizeram o bem, vão ressuscitar para a vida; os que praticaram o mal, vão ressuscitar para a condenação. (Jo 5,28)

\footnotetext{
5 Tivemos na Guerra dos Trinta Anos, por exemplo, a morte de Gustavo Adolfo, rei da Suécia, cuja morte destruiu o sonho sueco de ser uma potência europeia. O mesmo ocorrera a Portugal, quando D. Sebastião morre na batalha de Alcácer-Quibir, levando o país à penumbra da História durante quase um século.

6 Vale salientar a diferença que há entre a dança de esqueletos e a dança macabra: na primeira temos a representação que se dá somente entre esqueletos, ou seja, a morte já havia sido instaurada e - segundo uma superstição medieval - os mortos chamam uns aos outros para, de forma burlesca, imitar os vivos antes de ir buscá-los; na outra, os mortos - esqueletos - estão acompanhadas de pessoas vivas, cf. a série de gravuras de Hans Holbein, A dança macabra.
}

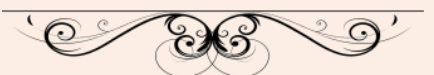




\section{Reuista Letear Racar}

ISSN: 2317-2347 - Vol. 5, Ano 5, № 2 - 2016

Podemos ver também na emblemática, formas eufemísticas de representação da morte e de sua relação com os homens, como a apresentada no emblema 89, Desiderans dissolvi, de Georgete de Montenay (fig. 14), em que a morte convida, acolhe e retira o homem do mundo - cuja representação é-nos dada pelo globo de onde o homem se retira - pelas mãos.

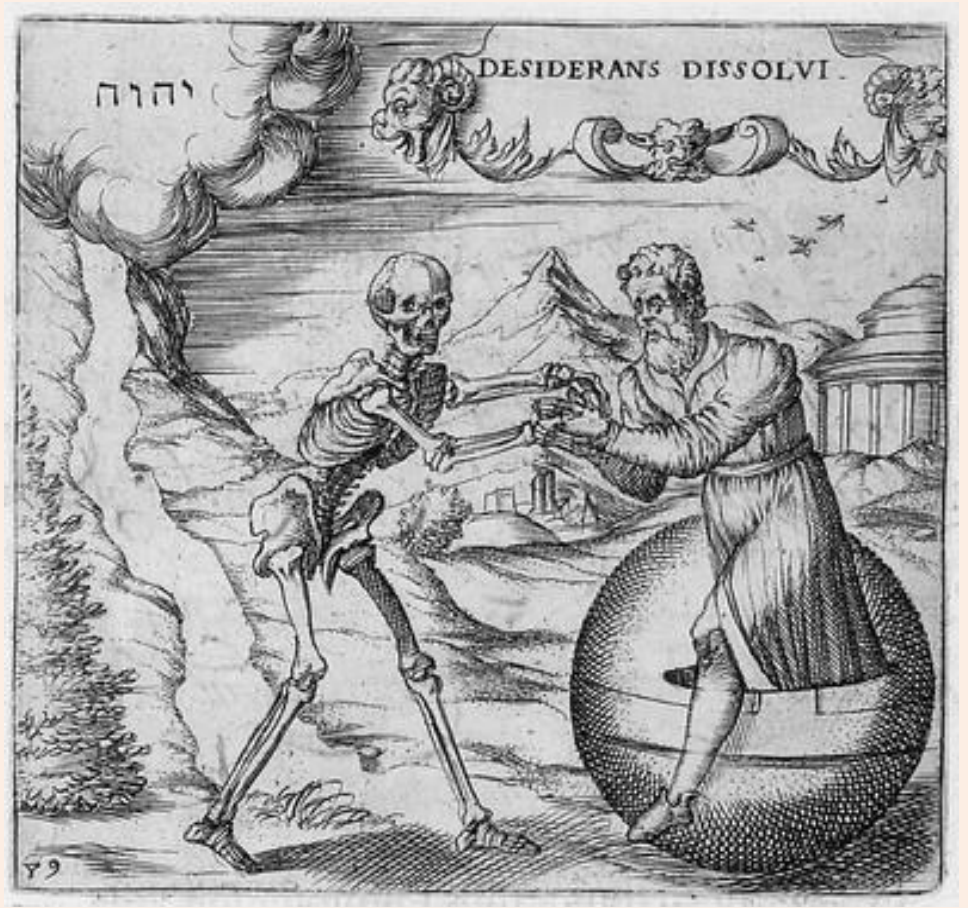

Figura 14: Emblema 89, Desiderans dissolvi, Georgete de Montenay, 1615.

\section{Ampulheta}

A ampulheta e o relógio de bolso, além de evocarem a velocidade fágica do tempo, dão consciência da degradação da matéria e da vida, representada pela perda do viço, pelo enrugamento no rosto, pelas gretas nos cantos da parede. Contudo, não representam a morte em si:

Sanduhr oder Stundenglas, nicht in erster Linie ein Symbol des Todes, sondern der Vergänglichkeit und des Verrinnens der Zeit, was naturgemäß auch ein »memento mori« (gedenke des Todes, bzw. der unaufhaltsam näherrückenden Todesstunde) mit einschließt. Das Stundenglas gehört in erster Linie zu den Attributen des Zeitgottes Chronos oder Aion. Da das Zeitmeßgerät immer wieder umgedreht werden muß, um funktionieren zu können, läßt es sich auch mit einem Weltbild zyklischer Zeitabläufe in 


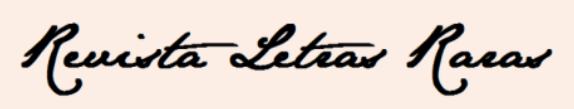

ISSN: 2317-2347 - Vol. 5, Ano 5, № 2 - 2016

Einklang bringen, also mit der »ewigen Wiederkehr« kosmischer Situationen $^{7}$. (Biedermann, 1998, p. 928)

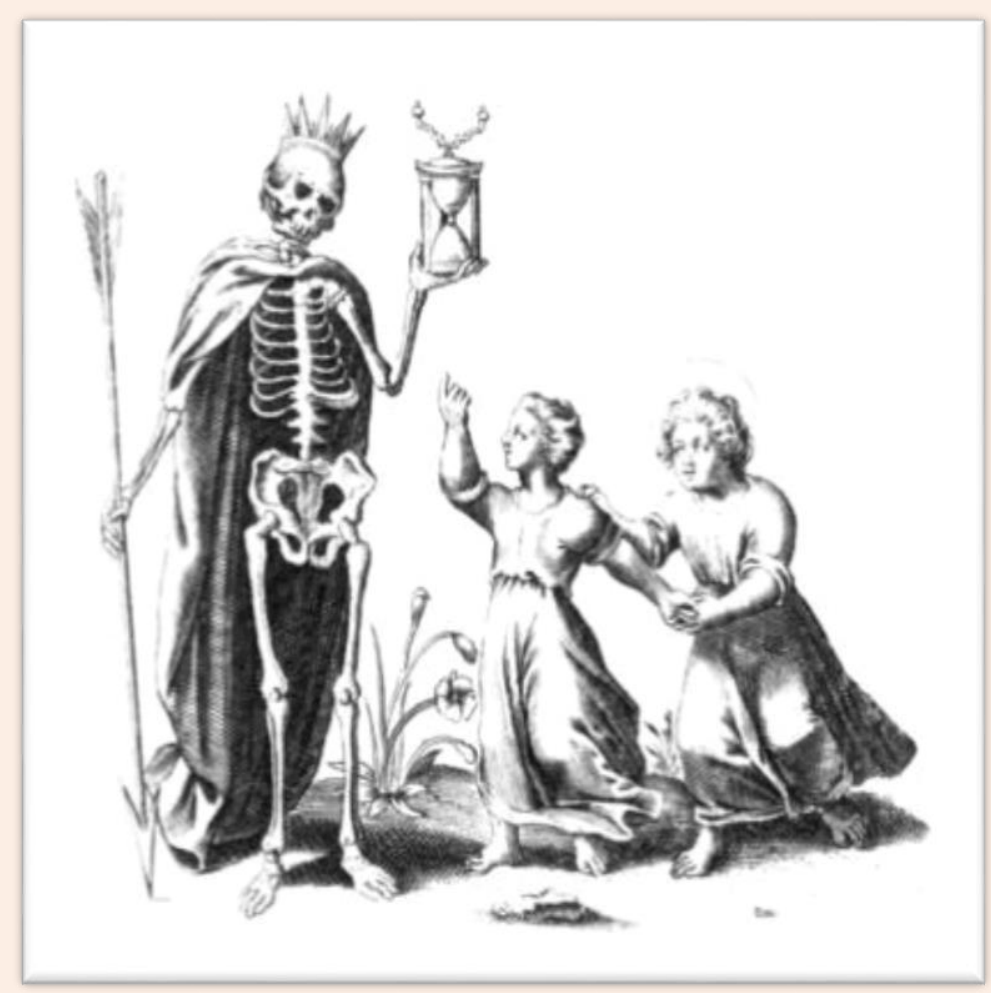

Figura 15: Emblema 12, Antipathia amoris et mortis, anônimo, 1628.

A subscriptio do emblema 12 (fig. 15), retirada do livro de Jó, demonstra-nos que o fim do eu-bíblico está próximo:

Como são poucos os dias da minha vida! Deixa-me, para que eu possa respirar um pouco, antes que eu me vá para nunca mais voltar, para o país da treva e da sombra da morte, para o país onde a aurora é noite negra, onde a sombra da morte cobre a confusão, e onde a claridade é escuridão. (Jó 10, 20-22)

Dessa forma, uma das intenções da utilização emblemática da ampulheta é demonstrar que, apesar de o termo estar próximo, é possível ainda ter uma chance (respirar um pouco) e buscar não só a conversão dos pecados, como também a virtude:

Als Aufforderung zur Tugend soll das Sanduhr-Symbol an die Mäßigkeit erinnern, damit die dem Menschen zugemessene Zeit nicht durch

\footnotetext{
${ }^{7}$ Ampulheta ou vidro das horas, que primeiramente não é símbolo da morte, mas da efemeridade e do correr do tempo, o que, portanto, engloba também um memento mori (lembra-te da morte, ou da chegada inexorável da morte). A ampulheta primeiramente faz parte dos atributos do deus do tempo, Cronos ou Aion. Já que a ampulheta deve ser virada continuamente para que funcione, ela pode ser associada a uma imagem do mundo com decursos cíclicos do tempo, ou seja, com o eterno retorno de situações cósmicas. [tradução nossa]
}

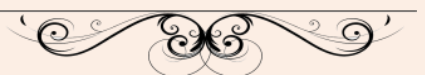




\section{Reuista Letras Racar}

ISSN: 2317-2347 - Vol. 5, Ano 5, № 2 - 2016

Ausschweifungen willkürlich abgekürzt werde. Die heiligen Asketen Ambrosius und Magdalena werden mit der Sanduhr dargestellt ${ }^{8}$. (BIEDERMANN, 1998, p. 928)

\section{Flores}

As flores não só agradam e dão prazer a nossos olhos, como também por seu meio é possível perceber como a beleza se esvai em tão pouco tempo. O maravilhoso odor, em breve, lembra a morte e seu domínio. Devido a isso, também representa a vanitas, já que o viço se esvai de forma fugaz. Sua origem, porém, não se encontra no Seiscentismo, mas na Bíblia: "Os dias do homem são como a relva, ele floresce como a flor do campo. Roça-lhe um vento, e já não existe". (S1 103,15-16)

Dentre as flores, a rosa merece um destaque especial, visto ser um dos temas recorrentes na poética dos Seiscentos, devido a seu frescor enquanto botão, à sua beleza ímpar e ao fato de ser rodeada por espinhos, cuja conotação será largamente empregada por poetas de todas as épocas.

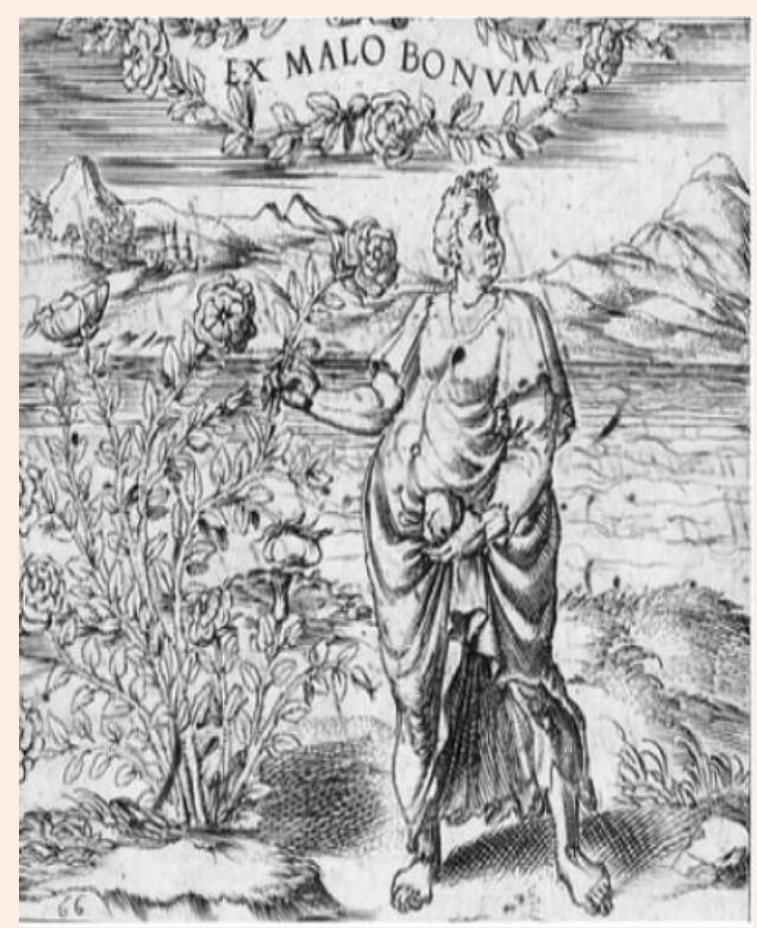

Figura 16: Emblema 66, Ex malo bonum, de Georgette de Montenay, 1615.

\footnotetext{
8 Como estímulo à virtude, o símbolo da ampulheta deve lembrar a medida. Para que o tempo concedido ao homem não seja encurtado, voluntariamente, por excessos. Os ascetas Santo Ambrósio e Madalena são representados por meio da ampulheta. [tradução nossa]
} 


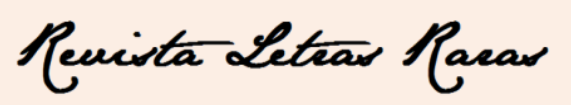

ISSN: 2317-2347 - Vol. 5, Ano 5, № 2 - 2016

Os espinhos, dentro da tradição cristã ocidental, remetem à coroa ${ }^{9}$ recebida por Cristo durante seu martírio; tendo, portanto, várias conotações negativas em relação à condição humana. Segundo Ambrósio (séc. IV d.C.), a rosa rodeada de espinhos representava a condição humana após a expulsão do homem do Paraíso e significaria Welt Wollust (prazer mundano). (JÖNS, 1966) Ambrósio recorreu ao Gênesis:

A terra produzirá para você espinhos e ervas daninhas, e você comerá a erva dos campos. Você comerá seu pão com o suor do seu rosto, até que volte para a terra, pois dela foi tirado. Você é pó, e ao pó retornará. (Gn 3, 18-19)

Ripa mostra-nos os espinhos para retratar a compunção:

Tiene los ojos vueltos hacia el Cielo y vierte copiosas lágrimas, llevando en la cabeza una corona de punzantes espinas. Sostiene con la izquierda un corazón, coronado de espinas igualmente (...).

Tiene además dos coronas de espinas (...) [y] representa la culpa contraída por el pecado; culpa que sin cesar punza y remuerde la conciencia, quedando simbolizada por la corona que en la cabeza lleva. (RIPA, 2007, p. 205-206)

Cristo é, em alguns poemas do período, visto como soberano imparcial, misericordioso e justo, daí a correspondência feita com a rosa, que exala perfume refrescante, mas possui espinhos que podem ferir. Picinelli, em seu emblema 211, cujo mote é Pungit \& recreat [punge e refresca], também emprega essa imagem da rosa, ao referir-se à natureza de Deus como a de Justitia \& Misericordia. (JÖNS, 1966) Georgette de Montenay, por sua vez, em seu emblema 66 Ex malo bonum [Do mal ao bom], também se refere à rosa e a seus espinhos, quando vemos uma mulher colhendo uma (fig. 16). Montenay afirma o poder da rosa em acalmar o peso do jugo, cuja representação mais comum é a figura de um boi em seu trabalho de arar a terra.Pode-se verificar, portanto, que, mais do que uma bela construção plástica, o quadro de Bailly traduz parte da Weltanschauung seiscentista de uma forma peculiar, mas que passaria despercebido aos olhos do leitor do século XXI. Evidentemente, há outras imagens que não foram abordadas neste artigo. No entanto, e isso deve ficar bem claro, elas não se

\footnotetext{
${ }^{9}$ Quando se fala em coroa de espinhos esquece-se, normalmente, do duplo caráter negativo desse ato dentro do mundo judaico. Primeiro, o ato pode ser visto como uma afronta/humilhação do homem judeu supliciado que diziam ser rei, porém não era aceito como tal por aqueles que o condenaram, logo atingiria a todos os presentes: eis seu rei - havia dito Pilatos; segundo, os antigos reis hebreus não recebiam coroa, eram ungidos com óleo. Seria, portanto, a constatação de uma pantomima da humilhação com seu gran finale: o fato de a mesma não ser de ouro, mas de espinhos, logo o rosto do futuro supliciado estaria eclipsado - lembrando Gregório de Matos devido ao sangue que jorrava dessas feridas.
}

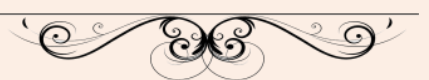




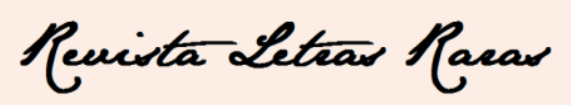

ISSN: 2317-2347 - Vol. 5, Ano 5, № 2 - 2016

prestavam apenas para "adornar plasticamente" uma obra, já que possuíam significação e estavam à disposição da fruição daqueles que podiam compreendê-las.

\section{Referências}

AUERBACH, Erich. Mímese: a representação da realidade na literatura ocidental. São Paulo, Perspectiva, 2004.

BENJAMIN, Walter. Origem do drama trágico alemão. Belo Horizonte: Autêntica, 2013.

BIEDERMANN, Hans. Knaurs Lexikon der Symbole. Berlin, Directmedia, 1998.

BÍBLIA SAGRADA: EDIÇÃO PASTORAL. São Paulo, Paulinas, 1990.

BRANDÃO, Antônio Jackson de S. Iconofotologia do Barroco alemão. Tese de doutorado apresentada à Universidade de São Paulo, 2008.

. "Sistemas de representação na arte barroca", in Revista Eutomia, UFPE,

2008.

. "O Lógos e a especificidade poética" in Revista Eutomia, UFPE, 2009.

CATS, Jacob. Sinne- en minnebeelden. Rotterdam (?), 1627 (Facsímile)

HOOFT, Pieter Cornelisz. Emblemata amatoria. Amsterdam, Zonnewyser, 1611 (Facsímile).

HORAPOLO. Hiroglyphica. Madrid, Ediciones Akal, 1991.

JÖNS, Dietrich Walter. "Das sinnen-Bild": Studien zur allegorischen Bildlichkeit bei

Andreas Gryphius. Stuttgart, J.B. Metzlersche Verlagsbuchhandlung, 1966.

MARAVALL, José Antonio. A cultura do Barroco: análise de uma estrutura histórica. São Paulo, 1997.

MONTENAY, Georgete. Emblematvm christianorvm centvria. Heildelberg, TYPIS Johannis Lancelloti, 1615 (Facsímile).

PANOFSKY, Erwin. Significado nas artes visuais. São Paulo, Perspectiva, 2001.

RIPA, Cesare. Iconología (Prólogo de Adita Allo Manero). Tomo 1. Madrid, Akal, 2007. 


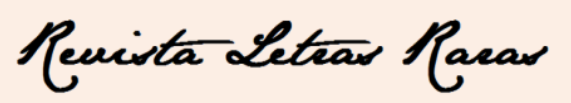

ISSN: 2317-2347 - Vol. 5, Ano 5, № 2 - 2016

VAENIUS, Otto. Qvinti horatii flacci emblemata: Imaginibus in æs incisis, Notisque illustrata. Antverpiæ, 1612 (Facsímile).

. Amoris divini emblemata. Antverpiæ, Ex officina Martini Nuti \& \& Ioannis Meursi, 1615 (Facsímile).

Recebido em: 06/10/2016

Aceito em: 10/10/2016 